\title{
Adélie penguins coping with environmental change: results from a natural experiment at the edge of their breeding range
}

\author{
Katie M. Dugger ${ }^{1 *}$, Grant Ballard ${ }^{2}$, David G. Ainley ${ }^{3}$, Phil O'B. Lyver ${ }^{4}$ and Casey Schine ${ }^{5}$ \\ ${ }^{1}$ U.S. Geological Survey, Oregon Cooperative Fish and Wildlife Research Unit, Department of Fisheries and Wildlife, Oregon State University, Corvallis, OR, USA \\ 2 Point Blue Conservation Science, Petaluma, CA, USA \\ ${ }^{3}$ H.T. Harvey and Associates, Los Gatos, CA, USA \\ ${ }^{4}$ Landcare Research, Lincoln, New Zealand \\ ${ }^{5}$ Department of Environmental Earth System Science, Stanford University, Stanford, CA, USA
}

\section{Edited by:}

Morten Frederiksen, Aarhus

University, Denmark

Reviewed by:

Nina Dehnhard, University of Antwerp, Belgium

Deborah Pardo, British Antarctic

Survey, UK

*Correspondence:

Katie M. Dugger, Oregon

Cooperative Wildlife Research Unit,

Department of Fisheries and

Wildlife, Oregon State University,

104 Nash Hall, Corvallis, OR

97331-3803, USA

e-mail:katie.dugger@

oregonstate.edu
We investigated life history responses to extreme variation in physical environmental conditions during a long-term demographic study of Adélie penguins at 3 colonies representing $9 \%$ of the world population and the full range of breeding colony sizes. Five years into the 14-year study (1997-2010) two very large icebergs (spanning 1.5 latitude degrees in length) grounded in waters adjacent to breeding colonies, dramatically altering environmental conditions during 2001-2005. This natural experiment allowed us to evaluate the relative impacts of expected long-term, but also extreme, short-term climate perturbations on important natural history parameters that can regulate populations. The icebergs presented physical barriers, not just to the penguins but to polynya formation, which profoundly increased foraging effort and movement rates, while reducing breeding propensity and productivity, especially at the smallest colony. We evaluated the effect of a variety of environmental parameters during breeding, molt, migration and wintering periods during years with and without icebergs on penguin breeding productivity, chick mass, and nesting chronology. The icebergs had far more influence on the natural history parameters of penguins than any of the other environmental variables measured, resulting in population level changes to metrics of reproductive performance, including delays in nesting chronology, depressed breeding productivity, and lower chick mass. These effects were strongest at the smallest, southern-most colony, which was most affected by alteration of the Ross Sea Polynya during years the iceberg was present. Additionally, chick mass was negatively correlated with colony size, supporting previous findings indicating density-dependent energetic constraints at the largest colony. Understanding the negative effects of the icebergs on the short-term natural history of Adélie penguins, as well as their response to long-term environmental variation, are important to our overall understanding of climate change effects in this and other species facing both rapid and persistent environmental change.

Keywords: Adélie penguin, breeding productivity, chick mass, climate change, environmental variation, nesting phenology

\section{INTRODUCTION}

Climate change effects on species' demographic parameters are increasingly evident across a broad range of taxa (Walther et al., 2002; Parmesan, 2006; Jenouvrier, 2013). This is especially evident at the poles, where massive changes in the extent and volume of glaciers and sea ice have occurred throughout geologic time, greatly altering the availability of habitat required for vertebrates to exist (for the Antarctic, see e.g., Emslie et al., 2007; Thatje et al., 2008). In recent decades, environmental changes attributable to anthropogenic climate change are more rapid and extensive than at any time in at least the past 1400 years (Kinnard et al., 2011; Stammerjohn et al., 2012). Species adapted to life in polar regions have had to adjust to such dramatic changes in the past, ostensibly by adjusting behavior, phenology, and ultimately distribution (Emslie et al., 2007; Thatje et al., 2008). However, the degree to which environmental change can be absorbed by a species' phenotypic coping mechanisms before long-term population changes occur remains largely unknown (reviewed in Barbraud et al., 2012). The unprecedented rate and magnitude of climate change occurring now provides an opportunity to assess species' capacity to adapt (Lescroël et al., 2014). At the same time, other environmental changes and their interactions with the direct effects of climate change have the potential for more rapid and consequential impacts on species' distributions and population dynamics than climate change alone (Warren et al., 2001; Jongsomjit et al., 2012; Jenouvrier, 2013). In particular, understanding the limits 
of the natural history and demographic attributes of ice-obligate species like the Adélie penguin (Pygoscelis adeliae) is of importance given the rapid increase in sea ice extent and persistence in the Ross Sea sector of the Southern Ocean over the past 30 years, particularly given these changes are in stark contrast with the Antarctic Peninsula sector and the Arctic Ocean (Stammerjohn et al., 2012).

Adélie penguin natural history has been well-studied Antarctic-wide (Ainley, 2002) with recent research focused on long-term temporal and spatial patterns in abundance and demographics (Jenouvrier et al., 2005; Dugger et al., 2006, 2010; Lynch et al., 2012a; Lyver et al., 2014), foraging ecology (e.g., Watanuki et al., 2002; Ainley et al., 2003, 2004; Ballard et al., 2010a; Lescroël et al., 2010, 2014), and breeding biology (Ainley et al., 1983; Emmerson and Southwell, 2008; Hinke et al., 2012). In summary, it appears that population responses of Adélie penguins to environmental drivers can vary temporally and spatially, with contrasting responses of vital rates to patterns of sea ice extent and/or concentration (Croxall et al., 2002; Forcada and Trathan, 2009; Ainley et al., 2010; Lynch et al., 2012a; Hinke et al., 2014). For example, increased summer sea ice concentrations near breeding colonies can result in decreased reproductive success (Ainley, 2002; Emmerson and Southwell, 2008) and foraging efficiency (Lescroël et al., 2014), but survival is lowest when winter sea ice concentrations are either very high or very low (Ballerini et al., 2009). Decreased summer sea ice extent 6 years previous can lead to increased populations (Jenouvrier et al., 2005), while extensive winter sea ice has been linked in a 5-year lag to decreased subadult survival (Wilson et al., 2001). The existence of polynyas (areas of persistent open water or low ice concentration within the larger sea ice field) is critical in affecting penguins' access to the ocean and thus, to food resources, because their presence reduces commuting time to foraging areas, thereby decreasing foraging effort and energy expenditure (Ballance et al., 2009; Ainley et al., 2010; Ballard et al., 2010a). Polynyas ultimately influence the distribution and persistence of Adélie penguin breeding colonies (Ainley, 2002; Arrigo and van Dijken, 2003) and the McMurdo Sound and Ross Sea polynyas are important to the distribution, persistence and size of the Ross Island penguin colonies that we study. Therefore, factors that disrupt or block these adjacent open water areas can have significant impacts on this species (Emslie et al., 2003; Ballard et al., 2010a; Lescroël et al., 2014).

During former millenia, changing ice conditions have caused major re-distributions of Adélie penguins in the Ross Sea, likely with associated effects on genetic diversity (Millar et al., 2012). Indeed, high rates of micro-evolution between ancient $(\sim 6000$ years ago) and modern populations have been documented for Adélie penguins (Shepherd et al., 2005), consistent with low emigration rates and high natal philopatry exhibited during periods of relatively stable environmental conditions (Ainley, 2002; LaRue et al., 2013). This is in contrast to overall genetic homogeneity documented for modern populations, and surprising for a species with such a large geographic distribution and general life history traits that should favor genetic differentiation (Roeder et al., 2001). However, millennia-scale environmental changes resulting in the southernmost portion of the Ross Sea being re-occupied only in the past $\sim 1100$ years (Emslie et al., 2003, 2007), large population sizes, extensive population re-distribution, and increased exchange between populations during periods of high environmental variation (Dugger et al., 2010), is likely responsible for this genetic homogeneity (Roeder et al., 2001; Shepherd et al., 2005).

Adélie penguin breeding populations are presently disappearing from areas in the Antarctic Peninsula that have been occupied for 500-800 years, beginning with onset of the Little Ice Age (Emslie, 2001). Thus, distributional shifts are once again occurring and have been linked to the rapid climate change in the region, including warming temperatures, increasing precipitation, and the disappearance of sea ice (Ducklow et al., 2007; Schofield et al., 2010; Lynch et al., 2012a) and associated penguin prey species (Sailley et al., 2013). In addition, the short breeding season associated with polar ecosystems results in a relatively inflexible breeding phenology (e.g., onset of laying, peak laying or hatch date) with limited opportunities for penguins to adjust to these rapid changes in foraging and nesting habitat at low latitudes (Hinke et al., 2012; Lynch et al., 2012b).

We have a 14-year time series (1997-2010) on demographics and breeding/foraging effort derived from three Adélie penguin colonies that vary in size by multiple orders of magnitude, within a 4-colony metapopulation in the Ross Sea (see Ainley, 2002; LaRue et al., 2013; Lyver et al., 2014; Figure 1). The objectives of this study were to use these data to determine the effect of typical seasonal variation in the sea ice environment at multiple spatial scales (i.e., Ross Sea sector of the Southern Ocean, the Ross Sea itself, and foraging areas adjacent to nesting colonies; Figure 2) on three important natural history parameters of Adélie penguins: breeding productivity, chick mass, and nesting chronology. After 5 years of this long-term study were completed, two giant icebergs grounded, one of which essentially constituted a fence 1.5 latitude degrees long ( $170 \mathrm{~km}$ in length; Figure 1), and dramatically altered local habitat conditions (Arrigo et al., 2002). This provided a "natural experiment" with which to evaluate smaller vs. extreme environmental perturbations that could alter important factors regulating colony size and persistence. During the middle third of the study period, the large icebergs brought extreme conditions by altering sea ice concentration (or cover; SIC), polynya formation, primary productivity and circulation (Arrigo et al., 2002; Robinson and Williams, 2012). In addition, because the icebergs were grounded and rose well above sea level, they created a physical barrier between the easternmost colony on Ross Island and the western colonies (Figure 1). The sea ice trapped by the icebergs during spring and summer when it usually breaks out, precluded development of the McMurdo Sound Polynya, and forced the penguins nesting at the western McMurdo Sound colonies to forage through a limited number of cracks in the sea ice or walk $50-70 \mathrm{~km}$ to reach open water. More importantly, the icebergs physically occupied the entire western marginal ice zone of the Ross Sea Polynya, one of the most ecologically prominent features of the region (Arrigo et al., 2002; Ballard et al., 2012; Figure 1), further reducing the availability of preferred foraging habitat (SIC <15\%; Ballard et al., 2010b; Lescroël et al., 2014). Thus, the presence of these icebergs provided a unique opportunity to investigate the impact of a severe, short-term habitat change on an ice-obligate species during a time 


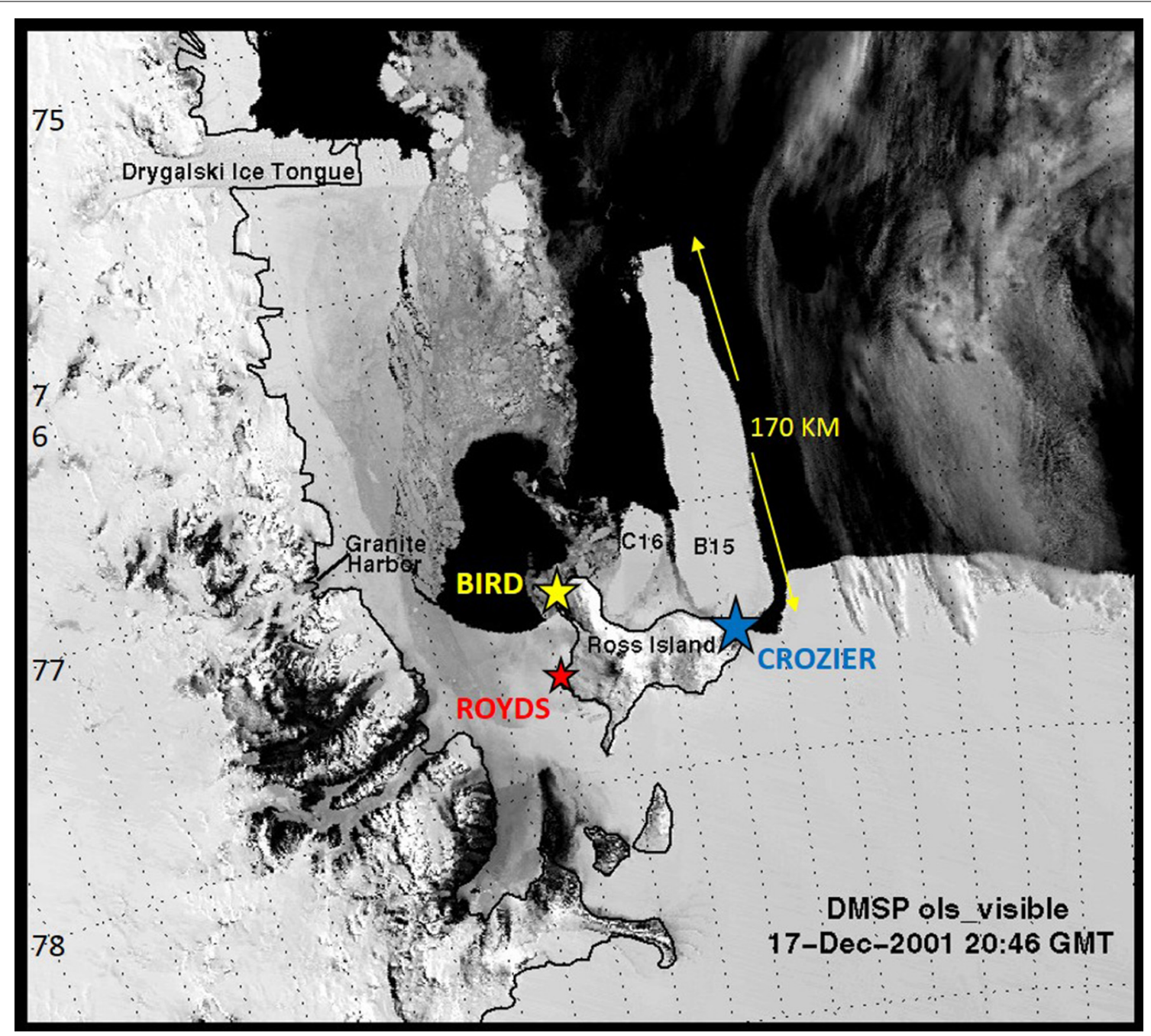

FIGURE 1 | Southern Ross Sea, Antarctica, and the locations of three Adélie penguin breeding colonies on Ross Island where reproductive performance parameters were collected from 1997 through 2010. Colonies vary in size by orders of magnitude, with
Cape Royds the smallest (mean size: 2865), Cape Bird intermediate (mean size: 43,321), and Cape Crozier the largest (mean size: 153,623). The positions of the giant icebergs (B15 and C16) in December 2001 are also indicated. when large-scale climate change was altering the region, including sea ice extent, duration of the sea ice season and polynya formation (cf. Parkinson, 2002; Zwally et al., 2002; Ainley et al., 2005, 2010; Stammerjohn et al., 2008, 2012). In addition, these data may help us to understand the mechanisms behind breeding colony formations and extirpations that have occurred infrequently in association with varying degrees of sea ice persistence in the region as the West Antarctic Ice Sheet withdrew from the Ross Sea during the Holocene (Emslie et al., 2003, 2007). These colonies were abandoned and then re-established at least twice during this time: 5000-4000 and 2000-1100 years B.P. (Emslie et al., 2003, 2007).

\section{MATERIALS AND METHODS}

Measures of reproductive performance, including breeding productivity, chick mass, and nesting chronology, were collected from three Adélie penguin colonies on Ross Island during 1997 through 2010 (Cape Royds, Bird, and Crozier). These colonies represent $9 \%$ of the global population as well as the full range of sizes of Adélie penguin colonies (cf. Lynch and LaRue, 2014), varying by multiple orders of magnitude (mean size, 19812012: Cape Royds: 2865, Cape Bird 43,321, and Cape Crozier 153,623 prs; most recent counts, 3083, 75696, and 272340, respectively; LaRue et al., 2013, 2014; Lyver et al., 2014). Access to food resources and intra- and inter-specific competition for food (Ainley et al., 2004, 2006; Ballance et al., 2009) are factors influencing the size-structure of the colonies in this meta-population. Nesting chronology was determined from the monitoring of marked nests at each colony, generally in association with data collection for other studies ( $n>30$ per site, per year; Ballard et al., 2001; Lescroël et al., 2009).

Breeding productivity (number of chicks per pair) was estimated from (1) ground counts of the number of occupied territories in a sample of subcolonies at each site (20-40 depending 


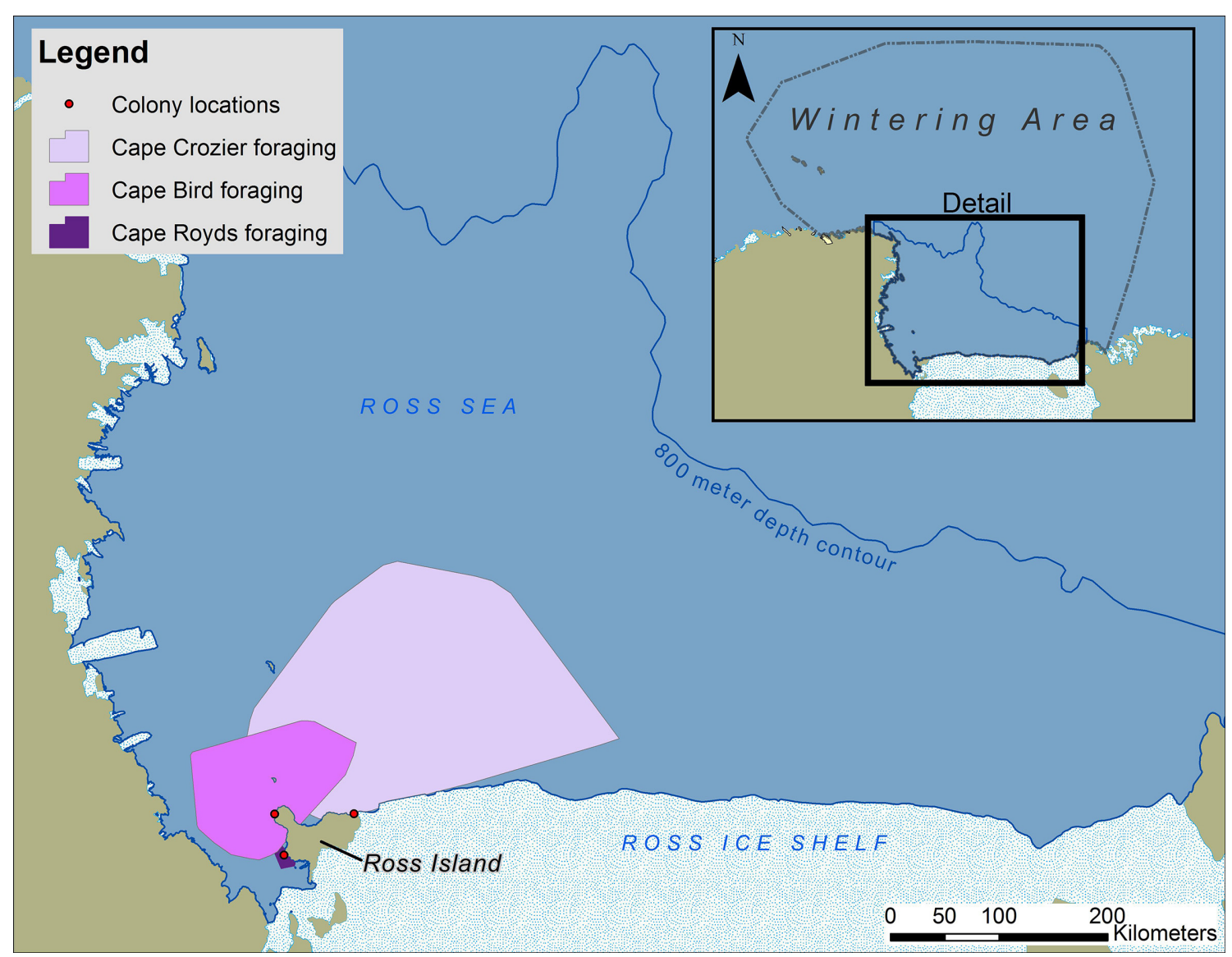

FIGURE 2 | Wintering, migration and foraging areas of Adélie penguins nesting at three colonies on Ross Island Antarctica, during 1997-2010.

on colony and year) conducted during late incubation (late November/early December) each year; and (2) counts of the number of chicks at each of these same subcolonies in mid-January. An overall mean number of chicks per pair for the entire sample of subcolonies was generated for each colony annually, and used as the dependent variable for modeling.

We determined mean chick mass (gr) from $\sim 50$ chicks measured 5 weeks after peak hatch date at each colony each year (Ainley, 2002; Whitehead et al., in review). For nesting chronology, we could not estimate onset of laying, since penguins arrived at some of our colonies and began laying eggs before we had access to field camps. However, mean annual hatch dates were determined each year from $>30$ nests monitored in reference subcolonies at each colony. A long-term mean peak hatch date was calculated from annual peak hatch dates (1997-2010), and a "relative peak hatch date" was then generated by subtracting each year's peak hatch date from the long term mean for that colony. This resulted in a "relative" peak hatch date each year where positive values were later than mean peak hatch date and negative values were earlier than mean peak hatch date. We standardized the peak hatch dates by colony long-term means, because the onset of laying differed by as much as 14 days between Crozier (closest colony to wintering areas) and Royds (most southern Adélie penguin colony in the world).
Estimation of sea ice conditions was based on monthly means taken from weekly passive imagery using the Special Sensor Microwave/Imager (SSMI, Cavalieri et al., 1996/2008), as follows: at the large scale, (a) sea ice concentration or cover (SIC; \% of ice in a given ocean area) in wintering areas and (b) SIC along migration routes in the Ross Sea (both delineated by Ballard et al., 2010b; see Figure 2); and, at the meso-scale, (c) distance to polynya edge in McMurdo Sound during the breeding season and (d) SIC within foraging areas adjacent to each colony during December (Table 1; Figure 2). To generate annual estimates of net primary production (NPP) for the Ross Sea, SIC was calculated from SSM/I imagery using the Polynya Signature Simulation Method (PSSM) algorithm (Markus and Burns, 1995) which computes sea ice presence/absence at $6.25 \mathrm{~km}$ resolution.

In addition to SIC, the icebergs called B-15A and C-16 calved from the Ross Ice Shelf in March 2000, and by January 2001 had lodged against Ross Island between Capes Crozier and Bird, projecting $180 \mathrm{~km}$ north (1.5 latitude degrees; Figure 1). The icebergs moved out of the area in July 2006, so 1997-2000 and 2006-2010 were considered "not impacted" by the cumulative effects of the icebergs, and years 2001-2005 were considered "iceberg" years (Lescroël et al., 2009, 2014; Ballard et al., 2010a). In addition, the McMurdo Sound Polynya (adjacent to Cape Royds and Bird), failed to develop at least once in the years before 
Table 1 | Acronyms and brief descriptions of environmental covariates used to model relative peak hatch date, annual productivity (chicks per pair), and mean chick mass at 5 weeks post-hatch for Adélie penguins breeding at Cape Royds, Cape Bird and Cape Crozier on Ross Island during 1997-2010.

\begin{tabular}{ll}
\hline Acronym & Description \\
\hline Year & $\begin{array}{l}\text { Categorical variable representing general } \\
\text { annual variation in time series. }\end{array}$ \\
\hline Colony & $\begin{array}{l}\text { Categorical variable representing } 3 \\
\text { breeding colonies on Ross Island. }\end{array}$ \\
\hline ColSize & $\begin{array}{l}\text { Continuous variable for the number of } \\
\text { breeding pairs as counted from aerial } \\
\text { photographs taken at the onset of } \\
\text { incubation each year ( Dec. 1st). }\end{array}$ \\
\hline Iceberg & $\begin{array}{l}\text { Categorical variable representing } \\
\text { presence/absence of iceberg. Iceberg was } \\
\text { present during 2001-2005 breeding } \\
\text { seasons and absent during 1997-2000, } \\
\text { and 2006-2010 seasons. }\end{array}$ \\
\hline
\end{tabular}

IceCover

Categorical variable denoting presence or absence of extensive sea ice in the McMurdo Sound that precluded typical formation of McMurdo Sound polynya. Ice cover was present during 1999, 2001-2002, 2004-2005, and 2008, and absent in 1997-1998, 2000, 2003, 2006-2007, 2009-2010.

\begin{tabular}{ll}
\hline Distlce & Continuous variable for the weekly \\
& distance $(\mathrm{km})$ to ice edge from each \\
colony, averaged by month during the & breeding season. We investigated \\
& November (Distlce_N), December \\
& (Distlce_D) and January (Distlce_J) \\
& monthly means.
\end{tabular}

RSice

Continuous variable for weekly \% ice cover in the entire Ross sea averaged for November (RSice_N), October (RSice_O), and both October and November (RSice).

\begin{tabular}{ll}
\hline WAice & $\begin{array}{l}\text { Continuous variable for weekly \% ice } \\
\text { cover for Adélie penguin wintering areas } \\
\text { averaged for October (WAice_O) and } \\
\text { October and November (WAice). }\end{array}$ \\
\hline FA_Dec & $\begin{array}{l}\text { Continuous variable for colony-specific } \\
\text { weekly \% ice cover averaged for } \\
\text { December for foraging areas adjacent to } \\
\text { Adélie penguin colonies. }\end{array}$ \\
\hline NPP & $\begin{array}{l}\text { Primary production in the Ross Sea during } \\
\text { 1997-2010. }\end{array}$
\end{tabular}

the iceberg (owing to reduced winds), but during iceberg years when it was very windy (2003) it did form normally. So in addition to the iceberg covariate, which incorporated the physical presence of the icebergs, we looked at the effects of extensive
SIC (in foraging areas) alone (hereafter referred to as IceCover; Table 1). Under this scenario, the 6 years during which sea ice remained in McMurdo Sound through chick rearing included 1999, 2001-2002, 2004-2005, and 2008.

Annual estimates of net primary production (NPP) for the Ross Sea were calculated by integrating daily estimates of NPP over the growing season from October 17- March 21. For this purpose, the Ross Sea was defined as the geographic area from 60 to $79^{\circ} \mathrm{S}$ and $160^{\circ} \mathrm{E}$ to $155^{\circ} \mathrm{W}$. Daily estimates of NPP (Tg C day-1) were calculated by spatially integrating daily maps of NPP over the area of open water. Daily NPP maps (mg C m-2 day1) were produced using satellite-derived chlorophyll $a(\mathrm{Chl} a)$, sea surface temperature, and sea ice cover using the algorithm detailed in Arrigo et al. (2008). Chlorophyll a concentrations were calculated for the years 1997 through 2002 from SeaWiFS Level 2 (4 km resolution) ocean color data (Reprocessing R2010.0), using the OC4v4 algorithm (O'Reilly et al., 1998). For October 2002 through March 2012, Chl $a$ concentrations were calculated from MODIS Aqua Level 2 ( $1 \mathrm{~km}$ resolution) ocean color data (Reprocessing R2012.0), using the OC3M algorithm (O'Reilly et al., 2000). Five-day averages were used for calculating NPP. Sea surface temperature used to calculate NPP was taken from the Daily Reynolds Optimally Interpolated SST (OISST) Version 2 product (Reynolds et al., 2002), from NOAA (www.ncdc.noaa. gov/oa/climate/research/sst/oi-daily.php).

Estimates of colony size, i.e., number of breeding pairs, were obtained from Lyver et al. (2014), and were based on counts derived from annual aerial photographs taken during late incubation ( December 1st) each year, concurrent with the ground counts described above. Using these data, we were able to include colony size directly as a continuous variable, rather than a more general categorical effect in models.

A variety of a priori models that reflected hypothesized relationships between reproductive performance and these environmental covariates, including colony size, were developed specific to each dependent variable (Supplementary Material). For example, we hypothesized that breeding productivity each year would most likely be influenced by factors that affected breeding propensity (i.e., the probability that a bird breeds each year) such as arrival date at the colony, and also foraging conditions during the breeding season adjacent to each colony. Therefore, the number of chicks per pair was modeled in relation to SIC on wintering areas and also for the Ross Sea in general during October and November, as we expected high SIC during this time to delay birds returning to breed. We hypothesized that delayed arrival from wintering areas each spring would likely affect adult body condition and delay onset of breeding (i.e., as measured here with relative peak hatch date).

In contrast, we predicted negative effects on chicks produced per pair and chick mass of SIC in foraging areas adjacent to each colony and/or distance to ice edge (polynya edge) in McMurdo Sound when chicks were being fed through December. We also expected a link between primary production in the Ross Sea and chick mass, with higher productivity resulting in heavier chicks. Due to differences in intraspecific competition as a function of colony size, we also predicted heavier chicks at the smaller colonies (Royds and Bird) compared to the largest (Crozier). 
Finally, similar to breeding productivity, we expected nesting chronology to be most strongly related to large-scale SIC during spring migration, with higher SIC resulting in later relative peak hatch dates at each colony. Thus, we generated models linking relative peak hatch date to SIC on wintering areas and on migration routes during October and November. SIC and sea ice extent at the large scale are strongly correlated (Zwally et al., 2002).

For each of the reproductive parameters (breeding productivity, chick mass, and nesting chronology) we used general linear models (SAS Proc Mixed; SAS Institute, Inc, 2008) to investigate the effects of continuous SIC covariates, primary production, and colony size, as well as categorical variables denoting years when icebergs or extensive SIC in McMurdo Sound were present. We investigated each of these covariates as a single additive effect and also 2-factor models containing colony or colony size, and iceberg presence or SIC as additive and interactive effects if those covariates received strong support as single-factor effects (Supplementary Material). We also included an interceptonly model and model containing general annual variation for comparison (Supplementary Material). We used an informationtheoretic approach including differences in model $\mathrm{AIC}_{c}$ compared to model with lowest $\mathrm{AIC}_{c}(\triangle A I C c), \mathrm{AIC}_{c}$ weights, and model coefficients (betas: $\beta$ ) to determine strength of evidence for models and specific effects within models (Burnham and Anderson, 2002). For the top models in each analysis we used a variance decomposition approach to determine the amount of variance explained by the best model (e.g., Franklin et al., 2000; Olson et al., 2004). We used changes in residuals generated by Proc Mixed in SAS (SAS Institute, Inc, 2008) in relation to the intercept-only model to separate the contribution of parameters in the model to overall variance in the dependent variable.

\section{RESULTS}

Breeding productivity was strongly affected by colony and iceberg presence with the best model indicating that these effects were additive (Model 1, Supplementary Material). The iceberg had a strong negative effect on breeding productivity as predicted $(\hat{\beta}=-0.60, S E=0.08,95 \% \mathrm{CI}:-0.44$ to -0.76$)$, and the effect was strongest at Royds (Figure 3); a pattern consistent with the second best model that included an interaction between iceberg presence and colony (Model 2, Supplementary Material). The top-ranked model containing the additive effects of iceberg and colony, explained $59.9 \%$ of the total variance in penguin productivity (Model 1, Supplementary Material). Thus, in conjunction with initial overall declines in breeding populations at all 3 colonies in relation to the presence of the iceberg (Lyver et al., 2014), on average, $\sim 2500,36,000$, and $>125,000$ fewer chicks per year were produced at Royds, Bird and Crozier, respectively, during the 5 years the icebergs were present.

If models including the iceberg effect and colony or colony size were not considered in our a priori model set, then the top models would have included significant positive effects of SIC in winter areas during October (Model 6; $\hat{\beta}=0.07, S E=$ 0.02 , 95\% CI: 0.04-0.11). Moreover, the negative effects of the average weekly distance $(\mathrm{km})$ to the ice edge/polynya edge in November (Model 8; $\hat{\beta}=-0.007, S E=0.002,95 \% \mathrm{CI}:-0.003$ to -0.011 ) and December (Model 7; $\hat{\beta}=-0.009, S E=0.002$, 95\% CI: -0.005 to -0.014 ) on penguin productivity would

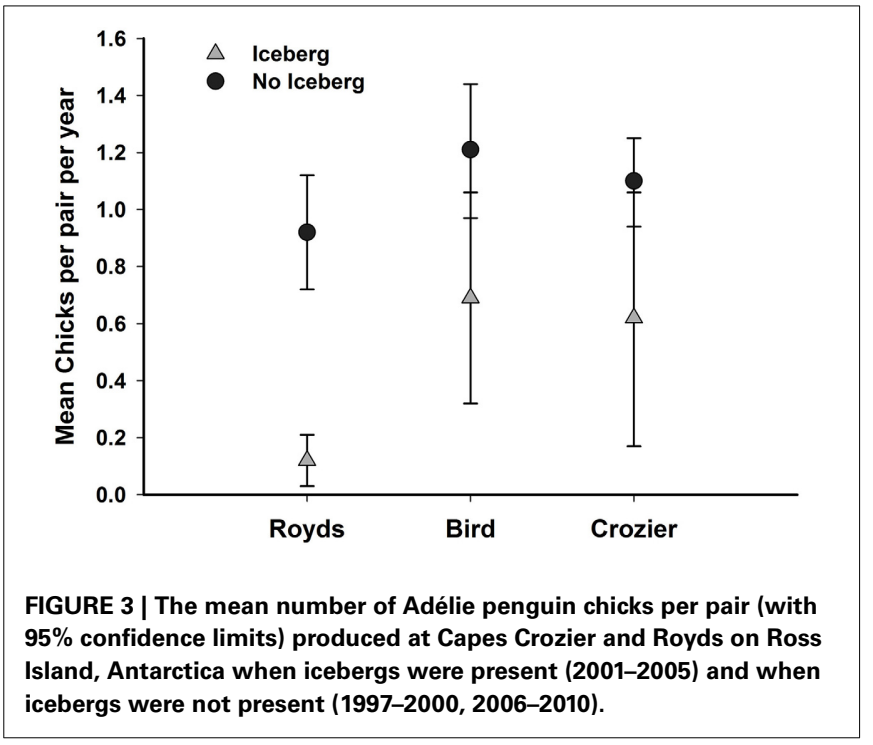

have received more support (Supplementary Material). A positive relationship between SIC on wintering and migration areas in October and the number of chicks produced per pair was contrary to what we hypothesized if high SIC delayed spring arrival or decreased breeding propensity, which could decrease productivity. We did predict that chick mass would increase with decreased distance to the ice edge/polynya edge during the breeding season, and as a consequence more chicks may survive, thereby increasing overall productivity.

Chick mass was lower at all 3 colonies when the iceberg was present, but interestingly, there was also a strong negative linear relationship between chick mass and colony size (Model 1, Supplementary Material; Figure 4), consistent with Whitehead et al. (in review). Chicks averaged $347 \mathrm{gr}(S E=98.6)$ heavier during non-iceberg years, but mass decreased $3 \mathrm{gr}(S E=0.6)$ with every 1000 breeding pair increase in colony size (Figure 4). The top model containing additive effects of both colony size and the iceberg effect received $77 \%$ of the $\mathrm{AIC}_{c}$ weight and explained $46.5 \%$ of the total variance in chick mass during this study. None of the other covariates received any support as evidenced by low $\mathrm{AIC}_{c}$ model weights (Supplementary Material), and even if the iceberg effect was not considered, the effect of colony size far outweighed the impact of any other covariate for these data.

When all years of available data were used in the nesting chronology analyses, relative peak hatch date was slightly earlier (0.46 days) during non-iceberg years, than during iceberg years (Model 1; iceberg absent: $\hat{\beta}=-1.422, S E=0.89,95 \%$ CI: 0.36 to -3.20 ; Supplementary Material). This top model only explained $3.4 \%$ of the total variance in relative peak hatch date, and confidence limits on this coefficient included zero, so the iceberg had only a weak effect on this parameter. However, this data set included outliers for Cape Royds and Crozier during the 2009 season, when mean peak hatch dates at both colonies were $>1$ week later than is typical because of a large asynchrony in timing of return to the breeding colonies. This was unrelated to the iceberg, or any apparent environmental conditions we investigated, but resulted in a peak of birds arriving with typical timing and another peak of birds arriving much later. If data from 2009 


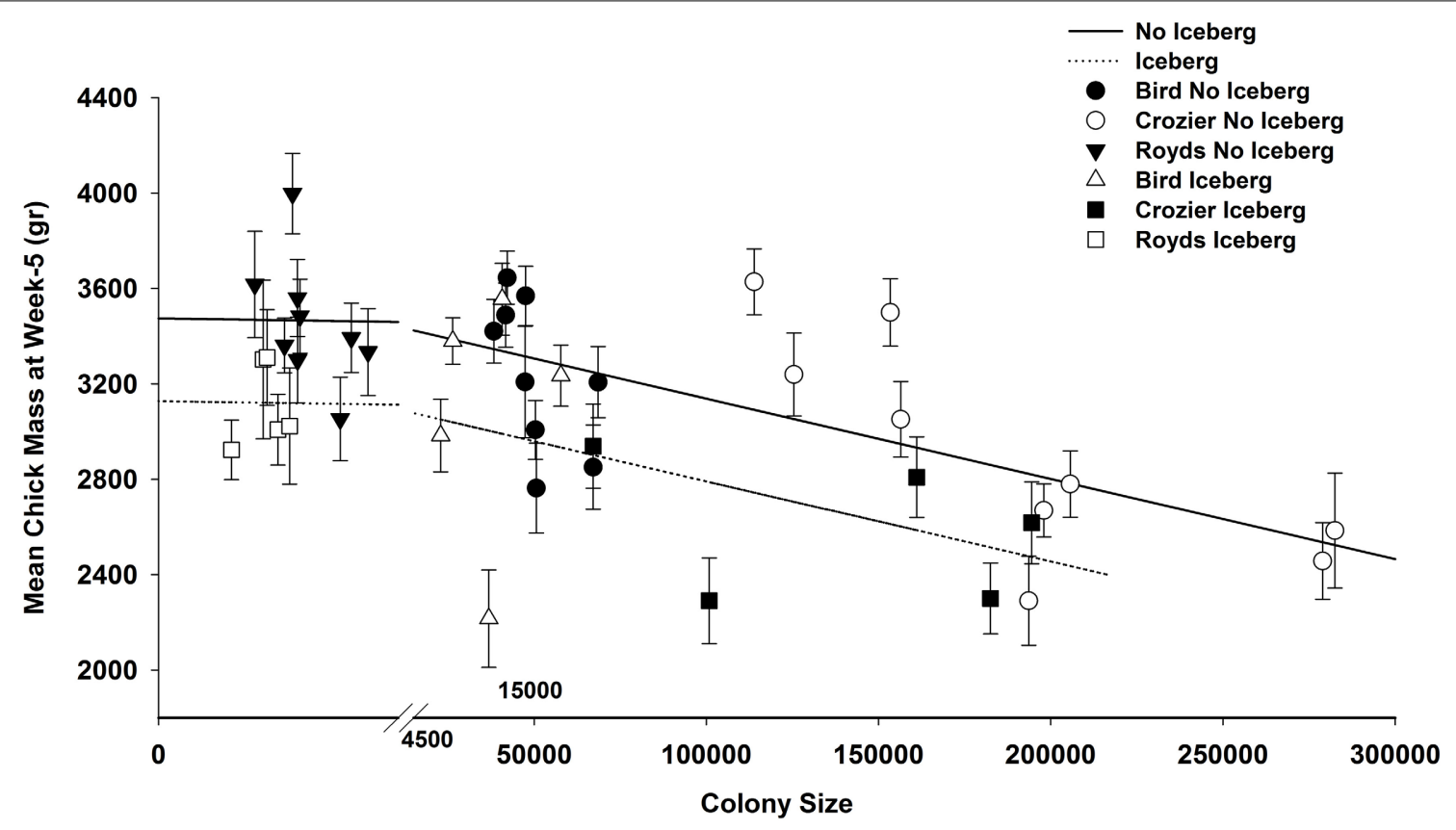

FIGURE 4 | Predicted mean mass (gr; with 95\% confidence limits) of chicks at $\mathbf{5}$ weeks post-peak hatch date from best model plotted against colony size, for Adélie penguin at Cape Royds, Bird, and

Crozier on Ross Island, Antarctica when icebergs were present (2001-2005) and when icebergs were not present (1997-2000, 2006-2008).

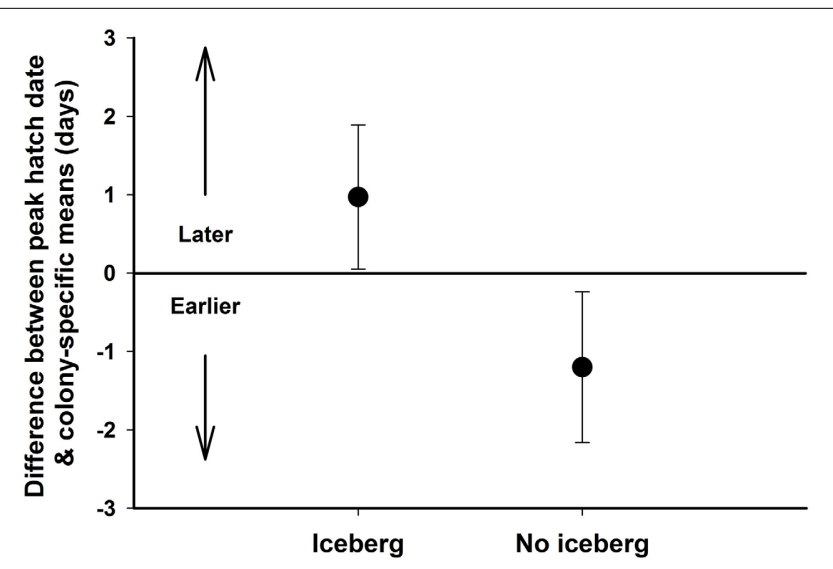

FIGURE 5 | The mean difference (with 95\% confidence limits) between peak hatch date and colony-specific means for Adélie penguin s breeding at Cape Royds, Bird, and Crozier on Ross Island, Antarctica during years when the icebergs were present (2001-2005) and when there were no icebergs, excluding 2009 (1997-2000, 2006-2008, 2010).

were excluded, the iceberg effect was stronger (Model 1; $\mathrm{AIC}_{c}$ $w t=0.78$; Supplementary Material), with the best model containing the iceberg effect explaining $17.3 \%$ of the total variance, and a coefficient with confidence limits that did not include zero $(\hat{\beta}=-2.12, S E=0.69,95 \%$ CI: -0.74 to -3.49$)$. Excluding 2009 , mean relative peak hatch dates were nearly 2 days earlier during years when the iceberg was not present (Figure 5).

When all years were considered, only the model with the iceberg effect (Model 1) ranked higher than the intercept-only model
(Model 2, Supplementary Material), indicating that none of the other covariates considered could explain much variation in relative peak hatch date if the iceberg effect was not considered. However, if 2009 was excluded, and the iceberg effect was not considered, then the mean weekly SIC for Adélie penguin wintering areas during October would have been the top model (Model 2, Supplementary Material). The direction of the effect is as anticipated, with more ice on wintering areas in October resulting in a later relative peak hatch date, with the confident limits on the coefficient just barely overlapping zero $(\hat{\beta}=-0.20, S E=0.11$, 95\% CI: 0.02 to -0.42 ). This indicates that although the effect of conditions during spring migration on breeding phenology in this study were weak, the relationship may be worth exploring in more detail with a longer time series.

\section{DISCUSSION}

The variation among measures of reproductive performance observed during years the icebergs were present was generally outside the range of variation seen in more typical years, with fewer chicks produced, lower chick mass, and delayed nesting chronology observed during iceberg years. Chick mass was also strongly negatively correlated with breeding population size (see also Whitehead et al., in review), lending support to previous findings suggesting that density-dependent energetic constraints exist at the largest colony (Ballance et al., 2009). When we excluded the effects of the iceberg perturbation, we also found weak support for the effect of SIC in October (spring migratory period) on breeding chronology (when 2009 was excluded) and some indication that distance to the ice or polynya edge during chickrearing affected the number of chicks per pair produced each 
year. However, none of the other environmental covariates had substantial effects on the population parameters we investigated even if the effect of the icebergs was not considered. The positive relationship between peak hatch date and SIC is consistent with sea ice extent being greater as well (Zwally et al., 2002), resulting in penguins wintering farther north than "normal" (cf. Ballard et al., 2010b), which could delay their arrival on breeding colonies in the spring and reduce breeding propensity, ultimately affecting colony size (Wilson et al., 2001).

Despite the fact that the levels of summer primary production, exhibited extreme variation in the Ross Sea during this study (5.749.6 $\mathrm{Tg} \mathrm{C}_{\text {year }}{ }^{-1}$ ) and was especially affected by the large icebergs, we were surprised that there was no effect on the penguin reproductive parameters we measured. Changing primary productivity, and correlated chlorophyll concentrations, have been found to affect the ecosystem in general (Schofield et al., 2010) and penguins in particular (Lynch et al., 2012a; Cimino et al., 2013) especially along the western coast of the Antarctic Peninsula, where climate change has been amplified. Chlorophyll concentration has been used as a proxy for food availability in many studies of seabirds and other upper level marine predators, however, the actual link between chlorophyll level and prey availability has rarely been made, and is likely very complex (e.g., Grémillet et al., 2008; Ainley et al., 2009; Suryan et al., 2011). Our results suggest that considering such a link should be done with caution and might be applicable only at larger spatial and temporal scales. At the scale of the entire Ross Sea there is a disproportionate contribution to total Southern Ocean productivity and an exemplary robust food web (cf. Arrigo et al., 1998; Ballard et al., 2012; Smith et al., 2014), perhaps mitigating any potential effects of more local variability in productivity.

The decline in reproductive performance during iceberg years had large effects on colony population size, particularly for the smallest colony in this meta-population. The three Ross Island colonies vary in size by multiple orders of magnitude and these large differences have affected natural history parameters, particularly in light of density-dependent and competitive effects on foraging effort and efficiency in this metapopulation (Ainley et al., 2004, 2006; Ballance et al., 2009). Additionally, the impacts of rare (in terms of a species' life span), but extreme environmental perturbation can be important for regulating population size (Drake, 2005; Frederiksen et al., 2008; Van de Pol et al., 2010), with extreme events predicted to have relatively larger effects on smaller populations compared to large ones, in part explaining why large Adélie penguin populations are large and small ones are small (Ballard, 2010). Indeed, the Royds breeding population decreased from 3600-3900 pairs before 2001 to $\sim 2200$ pairs by 2006; in contrast, the Crozier population increased from about 155,000 to $>175,000$ pairs during the iceberg years, and is now estimated to be over 270,000 breeding pairs (LaRue et al., 2014; Lynch and LaRue, 2014; Lyver et al., 2014). In addition, negative effects on productivity in particular are consistent with the decreased foraging efficiency (Ballard et al., 2010a; Lescroël et al., 2010, 2014) and increased inter-colony movement rates we observed for breeding adults (Dugger et al., 2010; LaRue et al., 2013) during this natural experiment. Movement rates of breeding adults between colonies increased in response to the presence of the icebergs, particularly emigration from Royds, the colony with the lowest productivity during those years (Dugger et al., 2010).

The variability inherent in demographic traits and life history characteristics are of particular interest given changing climate regimes, with gathering evidence indicating that some species lack the ability to adapt to the environmental variation they now face, with population declines and/or changes in distribution often the result (McLaughlin et al., 2002; Both et al., 2006; Lescroël et al., 2014). In fact, it has been suggested that Adélie penguins at the latitude of the Antarctic Peninsula region (northern edge of range) are less able to adjust their breeding chronology to warming temperatures, at least compared with Adélie penguins throughout their range (Ainley, 2002; Emmerson et al., 2011) and when compared to sympatric penguin species at the southern edge of their respective ranges (Hinke et al., 2012; Lynch et al., 2012b). However, in Tèrre Adélie, East Antarctica, Adélie penguins were found to change their laying date (later) but not arrival date in response to gradually changing ocean variables (Barbraud and Weimerskirch, 2006), and within the 18 latitude degrees in which Adélie penguins nest, spring arrival and laying vary by latitude (Ainley, 2002). For long-distance migratory birds in temperate climates, a disconnect between arrival on breeding grounds and the subsequent onset of reproduction, and peak food resources required to lay eggs and/or raise chicks has been reported (Visser et al., 1998, 2004; Both and Visser, 2001; Both et al., 2006). This disconnect has been linked directly (Both et al., 2006) and indirectly (Both et al., 2010) to population declines of these migratory species. At the northern limits of the Adélie penguin distribution (62-64S), sea ice disappearance has been linked to population declines (Ducklow et al., 2007; Schofield et al., 2010; Lynch et al., $2012 \mathrm{a}$ ), with decreases in prey availability as a function of sea ice also a factor (cf. Trivelpiece et al., 2011; Sailley et al., 2013). Other climate-related changes have been linked to changes in breeding phenology in these same areas, but there is currently no evidence indicating that changes in food abundance are responsible for changes in timing of reproduction or breeding success at these northern colonies (Hinke et al., 2012). Decreasing krill availability as cetaceans recover from whaling off East Antarctica, could explain the apparent shifts in date of laying (getting later) by Adélie penguins there (cf. Barbraud and Weimerskirch, 2006; Ainley et al., 2007, 2010), but it is generally unclear what demographic mechanisms (i.e., changes in survival, movements, or reproductive success) are driving the changes.

In the southern Ross sea, the southernmost edge of the species' breeding range (77-78S), Adélie penguins are likely very limited in their ability to shift breeding phenology because the summer season is very short relative to the time required to lay eggs and raise chicks to fledging ( $~ 85$ days; Taylor, 1962; Ainley, 2002). In addition, the Ross Island metapopulation has by far the longest migration for this species, a function of the distance between the southernmost location of the breeding colonies and the northern location of the outer pack ice, where the species winters because there is adequate light and suitable SIC (Ballard et al., 2010b; Ainley and Ballard, 2011). This species' ability to fast during portions of the breeding season helps them extend the time available to breed in southern Antarctica (Ainley, 2002), but arrival on the 
breeding grounds and the onset of breeding is triggered by day length (Ainley, 2002) and extending chick rearing later into the season would disrupt fall migration phenology and molt (Ainley, 2002; Ballard et al., 2010b). Our results show that the physical presence of the icebergs, which led to loss of polynya access for western Ross Island colonies and loss of the marginal ice zone for Crozier, had negative short-term consequences on this species' productivity at a population level, despite the fact that some individuals were able to cope with this environmental variation (Lescroël et al., 2010, 2014). In addition, given the delayed maturation of this species ( $\sim 3-7$ years age at first reproduction; Ainley, 2002), long-term effects on demography and breeding population size are still being realized, several years after the iceberg "experiment" terminated; indeed the Royds colony continued to decrease (down to $\sim 1800$ pairs), five years after return to typical polynya presence patterns (Lyver et al., 2014). For Adélie penguins in the Ross Sea, changes in breeding phenology, movements away from colonies most severely affected by the icebergs (Dugger et al., 2010), retention of birds on a colony where nesting habitat increased (LaRue et al., 2013), and selection for breeders who can forage most efficiently in the face of environmental stress (Lescroël et al., 2010, 2014) may reflect responses that can ameliorate short-term and even extreme environmental variability for this species (but see below).

This species has coped with multiple glacial advances in the past, and these long-term environmental changes resulted in substantial changes to breeding distributions lasting thousands of years (Emslie et al., 2007; Millar et al., 2012). If environmental conditions represented by the presence of icebergs during this study are analogous to increased SIC associated with the last "cooling" period that occurred $\sim 900$ years ago, severe declines in reproductive success may be one mechanism that facilitated breeding distribution changes documented during those geologic time periods (Emslie et al., 2007). Despite the fact that sea ice is currently increasing in the Ross Sea region owing to increasing winds (Thompson and Solomon, 2002; Russell et al., 2006; Stammerjohn et al., 2008, 2012), future conditions (next 50 years) are predicted to be quite different than conditions previously encountered by the species, as sea ice will eventually disappear on a much accelerated temporal scale (Ainley et al., 2010; Smith et al., 2014). The environmental conditions observed during this study when the icebergs were present (higher SIC), may appear anomalous to what we might expect given that the Antarctic climate generally is warming (Ainley et al., 2010). However, while the Ross Ice Shelf (West Antarctic Ice Sheet, WAIS) is believed to have been relatively stable over the last 100 years (Bentley, 1998), with calving events of large icebergs occurring every 30-40 years on average (Arrigo et al., 2002), calving rates have been high at times (within a geologic/glaciological context), as the WAIS retreated since the Last Glacial Maximum 20k years ago years (Conway et al., 1999; Emslie et al., 2007). In addition, warming climates might be expected to facilitate a future increase in calving rates and decrease overall ice shelf stability (Arrigo et al., 2002), as has been the case for ice shelves in the extreme northern part of Antarctica in recent years (Pritchard et al., 2009; Mulvaney et al., 2012). Thus, major calving events like the one we report on here are not new to Adélie penguins, and the conditions they experienced during the iceberg years illustrate the short-term environmental extremes and resulting population-level effects on reproductive performance that they must cope with at the most southern portion of their range. On a longer time scale, these southern colonies are at the forefront of range expansion in the face of WAIS retreat (with the accompanying hazard of large icebergs), while also coping concomitantly with increased distances from wintering areas in pack ice to the north (Ballard et al., 2010b).

\section{ACKNOWLEDGMENTS}

Funding was provided by National Science Foundation Grants OPP 9526865, 9814882, 0125608, 0944411 and 0440643 (to Katie M. Dugger, David G. Ainley, and Grant Ballard) and New Zealand's Ministry of Business, Innovation and Employment Grants C09X0510 and C01X1001 (to Phil O'B. Lyver). We offer many thanks to the large number of people who helped collect field data for this project over the last 14 years. Fieldwork was conducted with logistic support provided by the US Antarctic Program and Antarctica New Zealand. All penguin survey, capture and handling methods performed during data collection for this study were approved under appropriate Antarctic Conservation Act permits from the National Science Foundation Office of Polar Programs, Landcare Research Animal Ethics Committee Permit Programme and Oregon State University's Institutional Animal Care and Use Committee (ACUP \#3049, $3672,4130)$. We greatly appreciate comments made on earlier versions of this manuscript by Dr. Jefferson Hinke and two anonymous reviewers, and thanks to Dennis Jongsomjit (Point Blue Conservation Science) for his help revising figures. This is Point Blue Conservation Science Contribution No. 2000. Any use of trade, firm, or product names is for descriptive purposes only and does not imply endorsement by the U.S. Government.

\section{SUPPLEMENTARY MATERIAL}

The Supplementary Material for this article can be found online at: http://www.frontiersin.org/journal/10.3389/fevo.2014. 00068/abstract

\section{REFERENCES}

Ainley, D. G. (2002). The Adélie Penguin: Bellwether of Climate Change. New York, NY: Columbia University Press.

Ainley, D. G., and Ballard, G. (2011). Non-consumptive factors affecting foraging patterns in Antarctic penguins: a review and synthesis. Polar Biol. 35, 1-13. doi: 10.1007/s00300-011-1042-x

Ainley, D., Ballard, G., Ackley, S., Blight, L. K., Eastman, J. T., Emslie, S. T., et al. (2007). Paradigm lost, or, is top-down forcing no longer significant in the Antarctic Marine Ecosystem? Antarct. Sci. 19, 283-290. doi: 10.1017/S095410200700051X

Ainley, D. G., Ballard, G., Barton, K., Karl, B., Rau, G., Ribic, C., et al. (2003). Spatial and temporal variation of diet within a presumed metapopulation of Adélie penguins. Condor 105, 95-106. doi: 10.1650/00105422(2003) 105[95:SATVOD]2.0.CO;2

Ainley, D. G., Ballard, G., and Dugger, K. M. (2006). Competition among penguins and cetaceans reveals trophic cascades in the western Ross Sea, Antarctica. Ecology 87, 2080-2093. doi: 10.1890/00129658(2006)87[2080:CAPACR]2.0.CO;2

Ainley, D. G., Clarke, E. D., Arrigo, K., Fraser, W. R., Kato, A., Barton, K. J., et al. (2005). Decadal-scale changes in the climate and biota of the Pacific sector of the Southern Ocean, 1950s to the 1990s. Antarct. Sci. 17, 171-182. doi: 10.1017/S0954102005002567 
Ainley, D. G., Dugger, K. D., Ford, R. G., Pierce, S. D., Reese, D. C., Brodeur, R. D., et al. (2009). Association of predators and prey at frontal features in the California Current: competition, facilitation, and co-occurrence. Mar. Ecol. Prog. Ser. 389, 271-294. doi: 10.3354/meps08153

Ainley, D. G., LeResche, R. E., and Sladen, W. J. L. (1983). Breeding Ecology of the Adélie Penguin. Los Angeles, CA: University of California Press.

Ainley, D. G., Ribic, C., Ballard, G., Heath, S., Gaffney, I., Karl, B., et al. (2004). Geographic structure of Adélie penguin populations: overlap in colony-specific foraging areas. Ecol. Mono. 74, 159-178. doi: 10.1890/02-4073

Ainley, D. G., Russell, J., Jenouvrier, S., Woehler, E., Lyver, P. O’B., Fraser, W. R., et al. (2010). Antarctic penguin response to habitat change as Earth's troposphere reaches 28C above preindustrial levels. Ecol. Mono. 80, 49-66. doi: $10.1890 / 08-2289.1$

Arrigo, K. R., and van Dijken, G. L. (2003). Phytoplankton dynamics within 37 Antarctic coastal polynya systems. J. Geophys. Res. 108, 3271. doi: 10.1029/2002JC001739

Arrigo, K. R., van Dijken, G. L., Ainley, D. G., Fahnestock, M. A., and Markus, T. (2002). Ecological impact of a large Antarctic iceberg. Geophys. Res. Lett. 29, 8-1-8-4. doi: 10.1029/2001GLO14160

Arrigo, K. R., van Dijken, G. L., and Bushinsky, S. (2008). Primary production in the Southern Ocean. 1997-2006. J. Geophys. Res. 113, C08004. doi: 10.1029/2007JC004551

Arrigo, K. R., Worthen, D. L., Schnell, A., and Lizotte, M. P. (1998). Primary production in Southern Ocean waters. J. Geophy. Res. 103, 15,587-15,600.

Ballance, L. T., Ainley, D. G., Ballard, G., and Barton, K. (2009). Colony size and foraging effort in seabirds: is there an energetic correlate? J. Avian Bio. 40, 279-288. doi: 10.1111/j.1600-048X.2008.04538.x

Ballard, G. (2010). Biotic and Physical Forces as Determinants of Adélie Penguin Population Location and Size. Ph.D. thesis, University of Auckland, Auckland, New Zealand.

Ballard, G., Ainley, D. G., Ribic, C., and Barton, K. (2001). Effect of instrument attachment and other factors on foraging trip duration and nesting success of Adélie Penguins. Condor 103, 481-490. doi: 10.1650/00105422(2001)103[0481:EOIAAO]2.0.CO;2

Ballard, G., Dugger, K. M., Nur, N., and Ainley, D. G. (2010a). Foraging strategies of Adélie penguins: adjusting body condition to cope with environmental variability. Mar. Eco. Prog. Ser. 405, 287-302. doi: 10.3354/ meps08514

Ballard, G., Jongsomjit, D., Veloz, S. D., and Ainley, D. G. (2012). Coexistence of mesopredators in an intact polar ocean ecosystem: the basis for defining a Ross Sea marine protected area. Biol. Cons. 156, 72-82. doi: 10.1016/j.biocon.2011.11.017

Ballard, G., Toniolo, V., Ainley, D. G., Parkinson, C. L., Arrigo, K. R., and Trathan, P. N. (2010b). Responding to climate change: Adélie penguins confront astronomical and ocean boundaries. Ecology 91, 2056-2069. doi: 10.1890/ 09-0688.1

Ballerini, T., Tavecchia, G., Olmastroni, S., Pezzo, F., and Focardi, S. (2009). Nonlinear effects of winter sea ice on the survival probabilities of Adélie penguins. Oecol. 161, 253-265. doi: 10.1007/s00442-009-1387-9

Barbraud, C., and Weimerskirch, H. (2006). Antarctic birds breed later in response to climate change. Proc. Nat. Acad. Sci. U.S.A. 103, 6248-6251. doi: 10.1073/pnas.0510397103

Barbraud, C., Rolland, V., Jenouvrier, S., Nevoux, M., Delord, K., and Weimerskirch, H. (2012). Effects of climate change and fisheries bycatch on Southern Ocean seabirds: a review. Mar. Eco. Prog. Ser. 454, 285-307. doi: 10.3354/meps09616

Bentley, C. R. (1998). Rapid sea-level rise from a West Antarctic ice-sheet collapse: a short-term perspective. J. Glaciol. 44, 157-463.

Both, C., and Visser, M. E. (2001). Adjustment to climate change is constrained by arrival date in a long-distance migrant bird. Nature 411, 296-298. doi: $10.1038 / 35077063$

Both, C., Bouwhuis, S., Lessells, C. M., and Visser, M. E. (2006). Climate change and population declines in a long distance migratory bird. Nature 441, 81-83. doi: 10.1038/nature04539

Both, C., Van Turnhout, A. M., Bijlsma, R. G., Siepel, H., Van Strien, A. J., and Foppen, R. P. B. (2010). Avian population consequences of climate change are most severe for long-distance migrants in seasonal habitats. Proc. R. Soc. Lond. B Biol. Sci. 277, 1259-1266. doi: 10.1098/rspb.2009.1525
Burnham, K. P., and Anderson, D. R. (2002). Model Selection and Multimodel Inference: a Practical Information-Theoretic Approach, 2nd Edn. New York, NY: Springer-Verlag.

Cavalieri, D., Parkinson, C., Gloersen, P., and Zwally, H. J. (1996/2008). Sea Ice Concentrations from Nimbus-7 SMMR and DMSP SSM/I Passive Microwave Data, [1979-2007]. Boulder, CO: National Snow and Ice Data Center. Available online at: http://nsidc.org/data/

Cimino, M. A., Fraser, W. R., Irwin, A. L., and Oliver, M. J. (2013). Satellite data identify decadal trends in the quality of Pygoscelis penguin chick-rearing habitat. Glob. Chang. Biol. 19, 136-148, doi: 10.1111/gcb.12016

Conway, H., Hall, B. L., Denton, G. H., Gades, A. M., and Waddington, E. D. (1999). Past and future grounding-line retreat of the West Antarctic Ice Sheet. Science 286, 280-283. doi: 10.1126/science.286.5438.280

Croxall, J. P., Trathan, P. N., and Murphy, E. J. (2002). Environmental change and Antarctic seabird populations. Science 297, 1510-1514. doi: 10.1126/science. 1071987

Drake, J. M. (2005). Population effects of increased climate variation. Proc. R. Soc. Lond. B Biol. Sci. 272, 1823-1827. doi: 10.1098/rspb.2005.3148

Ducklow, H. W., Baker, K., Martinson, D. G., Quetin, L. B., Ross, R. M., Smith, R. C., et al. (2007). Marine pelagic ecosystems: the West Antarctic Peninsula. Proc. R. Soc. Lond. B Biol. Sci. 362, 67-94. doi: 10.1098/rstb.2006.1955

Dugger, K. M., Ainley, D. G., Lyver, P. O’B., Barton, K., and Ballard, G. (2010). Survival differences and the effect of environmental instability on breeding dispersal in an Adélie penguin meta-population. Proc. Nat. Acad. Sci. U.S.A. 107, 12375-12380. doi: 10.1073/pnas.1000623107

Dugger, K. M., Ballard, G., Ainley, D. G., and Barton, K. J. (2006). Effects of flipper bands on foraging behavior and survival of Adélie penguins (Pygoscelis adeliae). Auk 123, 858-869. doi: 10.1642/0004-8038(2006)123[858:EOFBOF]2.0.CO;2

Emmerson, L., and Southwell, C. (2008). Sea ice cover and its influence on Adélie penguin reproductive performance. Ecology 89, 2096-2102. doi: 10.1890/080011.1

Emmerson, L., Pike, R., and Southwell, C. (2011). Reproductive consequences of environment-driven variation in Adélie penguin breeding phenology. Mar. Ecol. Prog. Ser. 440, 203-216. doi: 10.3354/meps09265

Emslie, S. D. (2001). Radiocarbon dates from abandoned penguin colonies in the Antarctic Peninsula region. Antarct. Sci. 13, 289-295. doi: 10.1017/S0954102001000414

Emslie, S. D., Berkman, P. A., Ainley, D. G., Coats, L., and Polito, M. (2003). LateHolocene initiation of ice-free ecosystems in the southern Ross Sea, Antarctica. Mar. Eco. Prog. Ser. 262, 19-25. doi: 10.3354/meps 262019

Emslie, S. D., Coats, L., and Licht, K. (2007). A 45,000 yr record of Adélie penguins and climate change in the Ross Sea, Antarctica. Geology 35, 61-64. doi 10.1130/G23011A.1

Franklin, A. B., Anderson, D. R., Gutiérrez, R. J., and Burnham, K. P. (2000). Climate, habitat quality, and fitness in Northern Spotted Owl populations in northwestern California. Ecol. Mono. 70, 539-590. doi: 10.1890/00129615(2000)070[0539:CHQAFI]2.0.CO;2

Frederiksen, M., Daunt, F., Harris, M. P., and Wanless, S. (2008). The demographic impact of extreme events: stochastic weather drives survival and population dynamics in a long-lived seabird. J. Anim. Ecol. 77, 1020-1029. doi: 10.1111/j.1365-2656.2008.01422.x

Forcada, J., and Trathan, P. N. (2009). Penguin responses to climate change in the Southern Ocean. Glob. Chan. Biol. 15, 1618-1630. doi: 10.1111/j.13652486.2009.01909.x

Grémillet, D., Lewis, S., Drapeau, L., van Der Lingen, C. D., Huggett, J. A., Coetzee, J. C., et al. (2008). Spatial match-mismatch in the Benguela upwelling zone: should we expect chlorophyll and sea surface temperature to predict marine predator distributions? J. Appl. Ecol. 45, 610-621. doi: 10.1111/j.13652664.2007.01447.x

Hinke, J. T., Polito, M. J., Reiss, C. S., Trivelpiece, S. G., and Trivelpiece, W Z. (2012). Flexible reproductive timing can buffer reproductive success of Pygoscelis spp. penguins in the Antarctic Peninsula region. Mar. Ecol. Prog. Ser. 454, 91-104. doi: 10.3354/meps09633

Hinke, J. T., Trivelpiece, S. G., and Trivelpiece, W. Z. (2014). Adelie penguin (Pygoscelis adeliae) survival rates and their relationship to environmental indices in the South Shetland Islands, Antarctica. Polar Biol. doi: 10.1007/s00300-0141562-2. (in press).

Jenouvrier, S. (2013). Impacts of climate change on avian populations. Glob. Chang. Biol. 19, 2036-2057. doi: 10.1111/gcb.12195 
Jenouvrier, S., Barbraud, C., and Weimerskirch, H. (2005). Sea ice affects the population dynamics of Adélie penguins in Terre Adélie. Polar Biol. 29, 413-423. doi: 10.1007/s00300-005-0073-6

Jongsomjit, D., Stralberg, D., Gardali, T., Salas, L., and Wiens, J. A. (2012). Between a rock and a hard place: the impacts of climate change and housing development on breeding birds in California. Land. Ecol. 28, 187-200. doi: $10.1007 /$ s10980-012-9825-1

Kinnard, C., Zdanowicz, C. M., Fisher, D. A., Isaksson, E., de Vernal, A., and Thompson, L. G. (2011). Reconstructed changes in Arctic sea ice cover over the past 1450 years. Nature 479, 509-512. doi: 10.1038/nature10581

LaRue, M. A., Ainley, D. G., Swanson, M., Dugger, K. M., Lyver, P. O’B., Barton, K., et al. (2013). Climate change winners: receding ice fields facilitate colony expansion and altered dynamics in an Adélie Penguin metapopulation. PLoS ONE 8:e60568. doi: 10.1371/journal.pone.0060568

LaRue, M., Lynch, H. J., Lyver, P. O’B., Barton, K., Ainley, D. G., Pollard, A., et al. (2014). A method for estimating colony sizes of Adélie penguins using remote sensing imagery. Polar Biol. 37, 507-517. doi: 10.1007/s00300-014-1451-8

Lescroël, A., Ballard, G., Grémillet, D., Authier, M., and Ainley, D. G. (2014). Antarctic climate change: extreme events disrupt plastic phenotypic response in Adélie penguins. PLoS ONE 9:e85291. doi: 10.1371/journal.pone. 0085291

Lescroël, A., Ballard, G., Toniolo, V., Barton, K. J., Wilson, P. R., Lyver, P. O.'B., et al. (2010). Working less to gain more: when breeding quality relates to foraging efficiency. Ecology 91, 2044-2055. doi: 10.1890/09-0766.1

Lescroël, A., Dugger, K. M., Ballard, G., and Ainley, D. G. (2009). Effects of individual quality, reproductive success and environmental variability on survival of a long-lived seabird. J. Anim. Ecol. 78, 798-806. doi: 10.1111/j.13652656.2009.01542.x

Lynch, H. J., Fagan, W. F., Naveen, R., Trivelpiece, S. G., and Trivelpiece, W. Z. (2012b). Differential advancement of breeding phenology in response to climate may alter staggered breeding among sympatric pygoscelid penguins. Mar. Ecol. Prog. Ser. 454, 135-145. doi: 10.3354/meps09252

Lynch, H. J., Naveen, R., Trathan, P. N., and Fagan, W. F. (2012a). Spatially integrated assessment reveals widespread changes in penguin populations on the Antarctic Peninsula. Ecology 93, 1367-1377. doi: 10.1890/11-1588.1

Lynch, H. J., and LaRue, M. A. (2014). First global census of the Adélie penguin. Auk 131, 457-466. doi: 10.1642/Auk-14-31.1

Lyver, P. O’B., Barron, M., Barton, K. J., Ainley, D. G., Pollard, A., Gordon, S., et al. (2014). Trends in the breeding population of Adélie Penguins in the Ross Sea, 1981-2012: a coincidence of climate and resource extraction effects. PLoS ONE 9:e91188. doi: 10.1371/journal.pone.0091188

Markus, T., and Burns, B. A. (1995). A method to estimate subpixel-scale coastal polynyas with satellite passive microwave data. J. Geophys. Res. 100, 4473-4487. doi: 10.1029/94JC02278

McLaughlin, J. F., Hellmann, J. J., Boggs, C. L., and Ehrlich, P. R. (2002). Climate change hastens population extinctions. Proc. Nat. Acad. Sci. U.S.A. 99 6070-6074. doi: 10.1073/pnas.052131199

Millar, C. D., Subramanian, S., Heupink, T. H., Swaminathan, S., Baroni, C., and Lambert, D. M. (2012). Adélie penguins and temperature changes in Antarctica: a long-term view. Int. Zoo. 7, 113-120. doi: 10.1111/j.1749-4877.2012.00288.x

Mulvaney, R., Abram, N. J., Hindmarsh, R. C., Arrowsmith, C., Fleet, L., Triest, J., et al. (2012). Recent Antarctic Peninsula warming relative to Holocene climate and ice-shelf history. Nature 489, 141-144. doi: 10.1038/nature11391

Olson, G. S., Glenn, E. M., Anthony, R. G., Forsman, E. D., Reid, J. A., Loschl, P. J., et al. (2004). Modeling demographic performance of Northern Spotted Owls relative to forest habitat in Oregon. J. Wildl. Manage. 68, 1039-1053.

O’Reilly, J. E., Maritorena, S., Mitchell, B. G., Siegel, D. A., Carder, K. L., Garver, S., et al. (1998). Ocean color chlorophyll algorithms for SeaWiFS. J. Geophys. Res. 103, 24937-24953. doi: 10.1029/98JC02160

O’Reilly, J. E., Maritorena, S., O’Brien, M. C., Siegel, D. A., Toole, D., Menzies, D., et al. (2000). "SeaWiFS postlaunch calibration and validation analyses, Part 3," in NASA Technical Memorandum, 2000-206892, Vol. 11, eds S. B. Hooker and E. R. Firestone (Greenbelt, MD: NASA Goddard Space Flight Center), 49.

Parkinson, C. L. (2002). Trends in the length of the Southern Ocean sea-ice season, 1979-99. Ann. Glaciol. 34, 435-440. doi: 10.3189/172756402781817482

Parmesan, C. (2006). Ecological and evolutionary responses to recent climate change. Ann. Rev. Ecol. Evol. Syst. 37, 637-639. doi: 10.1146/annurev.ecolsys. 37.091305.110100
Pritchard, H. D., Arthern, R. J., Vaughan, D. G., and Edwards, L. A. (2009) Extensive dynamic thinning on the margins of the Greenland and Antarctic ice sheets. Nature 461, 971-975. doi: 10.1038/nature08471

Reynolds, R. W., Rayner, N. A., Smith, T. M., Stokes, D. C., and Wang, W. (2002). An improved in situ and satellite SST analysis for climate. J. Clim. 15, 1609-1625. doi: 10.1175/1520-0442(2002)015<1609:AIISAS > 2.0.CO;2

Robinson, N. J., and Williams, M. J. M. (2012). Iceberg-induced changes to polynya operation and regional oceanography in the southern Ross Sea, Antarctica, from in situ observations. Antarct. Sci. 24, 514-526. doi: 10.1017/S0954102012 000296

Roeder, A. D., Marshall, R. K., Mitchelson, A. J., Visagathilagar, T., Ritchie, P. A., Love, D. R., et al. (2001). Gene flow on the ice: genetic differentiation among Adélie penguin colonies around Antarctica. Mol. Ecol. 10, 1645-1656. doi: 10.1046/j.0962-1083.2001.01312.x

Russell, J. L., Dixon, K. W., Gnanadesikan, A., Stouffer, R. J., and Toggweiler, J. R. (2006). The Southern Hemisphere westerlies in a warming world: propping open the door to the deep ocean. J. Clim. 19, 6382-6390.

SAS Institute, Inc. (2008). SAS/STAT ${ }^{\circledR} 9.2$ Users Guide. Cary, NC: SAS Institute, Inc.

Sailley, S. F., Ducklow, H. W., Moeller, H. V., Fraser, W. R., Schofield, O. M., Steinberg, D. K., et al. (2013). Carbon fluxes and pelagic ecosystem dynamics near two western Antarctic Peninsula Adélie penguin colonies: an inverse model approach. Mar. Ecol. Prog. Ser. 492, 253-272. doi: 10.3354/ meps 10534

Schofield, O., Ducklow, H. W., Martinson, D. G., Meredith, M. P., Moline, M. A. and Fraser, W. R. (2010). How do polar marine ecosystems respond to rapid climate change? Science 328, 1520-1523. doi: 10.1126/science.1185779

Shepherd, L. D., Millar, C. D., Ballard, G., Ainley, D. G., Wilson, P. R., Haynes, G. D., et al. (2005). Microevolution and mega-icebergs in the Antarctic. Proc. Nat. Acad. Sci. U.S.A. 102, 16717-16722. doi: 10.1073/pnas. 0502281102

Smith, W. O. Jr., Dinniman, M. S., Hofmann, E. E., and Klinck, J. M. (2014). The effects of changing winds and temperatures on the oceanography of the Ross Sea in the 21st century. Geophys. Res. Let. 41, 1624-1631. doi: 10.1002/2014GL 059311

Stammerjohn, S. E., Martinson, D. G., Smith, R. C., Yuan, X., and Rind, D. (2008). Trends in Antarctic annual sea ice retreat and advance and their relation to ENSO and Southern Annular Mode variability. J. Geophys. Res. 113, C03S90, doi: 10.1029/2007JC004269

Stammerjohn, S., Massom, R., Rind, D., and Martinson, D. (2012). Regions of rapid sea ice change: an inter-hemispheric seasonal comparison. Geophys. Res. Let. 39, L06501, doi: 10.1029/2012GL050874

Suryan, R. M., Santora, J. A., and Sydeman, W. J. (2011). New approach for using remotely sensed chlorophyll $a$ to identify seabird hotspots. Mar. Ecol. Prog. Ser. 451, 213-225. doi: 10.3354/meps09597

Taylor, R. H. (1962). The Adélie Penguin Pygoscelis adeliae at Cape Royds. Ibis 104, 176-204.

Thatje, S., Hillenbrand, C.-D., Mackensen, A., and Larter, R. (2008). Life hung by a thread: endurance of Antarctic fauna in glacial periods. Ecology 89, 682-692. doi: 10.1890/07-0498.1

Thompson, D. W. J., and Solomon, S. (2002). Interpretation of recent Southern Hemisphere climate change. Science 296, 895-899. doi: 10.1126/science.1069270

Trivelpiece, W. Z., Hinke, J. T., Miller, A. K., Reiss, C. S., Trivelpiece, S. G., and Watters, G. M. (2011). Variability in krill biomass links harvesting and climate warming to penguin population changes in Antarctica. Proc. Nat. Acad. Sci. U.S.A. 108, 7625-7628. doi: 10.1073/pnas.1016560108

Van de Pol, M., Ens, B. J., Heg, D., Brouwer, L., Krol, J., Maier, M., et al. (2010). Do changes in the frequency, magnitude and timing of extreme climatic events threaten the population viability of coastal birds? J. Appl. Ecol. 47, 720-730. doi: 10.1111/j.1365-2664.2010.01842.x

Visser, M. E., Both, C., and Lambrechts, M. M. (2004). Global climate change leads to mistimed avian reproduction. Adv. Ecol. Res. 35, 89-110. doi: 10.1016/S00652504(04)35005-1

Visser, M. E., Van Noordwijk, A. J., Tinbergen, J. M., and Lessells, C. M. (1998). Warmer springs lead to mistimed reproduction in great tits (Parus major). Proc. R. Soc. Lond. B Biol. Sci. 265, 1867-1870.

Walther, G.-R., Post, E., Convey, P., Menzel, A., Parmesan, C., Beebee, T. J. C., et al. (2002). Ecological responses to recent climate change. Nature 416, 389-395. doi: $10.1038 / 416389$ a 
Warren, M. S., Hill, J. K., Thomas, J. A., Asher, J., Fox, R., Huntley, B., et al. (2001). Rapid responses of British butterflies to opposing forces of climate and habitat change. Nature 414, 65-69. doi: 10.1038/ 35102054

Watanuki, Y., Kato, A., Sato, K., Niizuma, Y., Bost, C. A., Le Maho, Y., et al. (2002). Parental mass change and food provisioning in Adélie penguins rearing chicks in colonies with contrasting sea-ice conditions. Polar Biol. 25, 672-681. doi: 10.1007/s00300-002-0399-2

Wilson, P. R., Ainley, D. G., Nur, N., Jacobs, S. S., Barton, K. J., Ballard, G., et al. (2001). Adélie penguin population change in the pacific sector of Antarctica: relation to sea-ice extent and the Antarctic Circumpolar Current. Mar. Ecol. Prog. Ser. 213, 301-309. doi: 10.3354/meps 213301

Zwally, H. J., Comiso, J. C., Parkinson, C. L., Cavalieri, J. L., and Gloersen, P. (2002). Variability of Antarctic sea ice 1979-1998. J. Geophys. Res. 107, C5 doi: 10.1029/2000JC000733
Conflict of Interest Statement: The authors declare that the research was conducted in the absence of any commercial or financial relationships that could be construed as a potential conflict of interest.

Received: 28 July 2014; accepted: 06 October 2014; published online: 24 October 2014. Citation: Dugger KM, Ballard G, Ainley DG, Lyver PO'B and Schine C (2014) Adélie penguins coping with environmental change: results from a natural experiment at the edge of their breeding range. Front. Ecol. Evol. 2:68. doi: 10.3389/fevo.2014.00068

This article was submitted to Interdisciplinary Climate Studies, a section of the journal Frontiers in Ecology and Evolution.

Copyright (c) 2014 Dugger, Ballard, Ainley, Lyver and Schine. This is an openaccess article distributed under the terms of the Creative Commons Attribution License (CC BY). The use, distribution or reproduction in other forums is permitted, provided the original author(s) or licensor are credited and that the original publication in this journal is cited, in accordance with accepted academic practice. No use, distribution or reproduction is permitted which does not comply with these terms. 